\title{
Pemanfaatan Sereh Wangi (Cymbopogon Nardus) sebagai Cairan Spray Anti Nyamuk (Repellant) pada Murid SD Muhammadiyah Pontianak
}

\author{
Asri Mulya Azhari', Mega Sari Juane Sofiana ${ }^{2 *}$, Warsidah ${ }^{2}$, Agus Yuliono ${ }^{3}$ \\ ${ }^{1}$ Prodi Agroteknologi, Fakultas Pertanian, Universitas Tanjungpura Pontianak \\ ${ }^{2}$ Prodi Ilmu Kelautan, Fakultas MIPA, Universitas Tanjungpura Pontianak \\ ${ }^{3}$ Prodi Antropologi Sosial, Fakultas ISIP, Universitas Tanjungpura Pontianak \\ *Correspondent Author: msofiana@marine.untan.ac.id
}

\begin{abstract}
ABSTRAK
Malaria adalah penyakit yang disebabkan oleh parasit plasmodium dengan perantara nyamuk anopheles dan penyakit Demam Berdarah Dengue (DBD) disebabkan oleh virus Dengue fever dengan perantara nyamuk Aedes aegepty. Kedua penyakit ini rawan mewabah di wilayah tropis ataupun subtropics terutama saat musim hujan yang menyebabkan terjadinya genangan air di mana-mana. Upaya pemerintah dalam mengintervensi mewabahnya penyakit DBD dan malaria adalah dengan usaha prefentif dan kuratif dari dinas terkait tentang pentingnya menjaga kesehatan keluarga dan dari gigitan nyamuk yang berpotensi menularkan penyakit malaria dan DBD. Kegiatan Pengabdian kepada Masyarakat ini sebagai salah satu implementasi dari tri dharma perguruan tinggi, dilakukan melalui pelatihan pemanfaatan sereh wangi sebagai cairan spray anti nyamuk pada siswa Sekolah Dasar Muhammadiyah 2 Pontianak. Metode kegiatan didasarkan pada pembuatan cairan antinyamuk berbahan baku ekstrak minyak atsiri sereh wangi (Cymbopogon nardus) yang dapat diaplikasikan pada botol spray untuk disemprotkan ke dalam suatu ruangan agar tidak dikunjungi oleh nyamuk. Kegiatan ini bertujuan untuk meningkatkan keterampilan anak SD Muhammadiyah 2 Pontianak dalam memformulasi minyak antinyamuk cair yang dapat digunakan sebagai pengusir nyamuk. Minyak atsiri sereh wangi dibuat dengan metode destilasi uap air di mana sejumlah bobot sampel minyak sereh wangi dipotong kecil disari dalam panci destilasi menggunakan uap air panas, menghasilkan uap panas yang kemudian terkondensasi menjadi tetes-tetes minyak. Tetes minyak yang dihasilkan selanjutnya di larutak dalam sejumlah kecil alkohol agar tercampur homogen antara minyak sereh wangi dengan air yang dengan mudah dapat diaplikasikan ke dalam botol spray. Selanjutnya dilakukan pengujian tentang kemampuan minyak sereh spray dalam mengusir nyamuk dari suatu ruang pengujian. Dari kegiatan PKM yang dihadiri oleh 15 anak SD menunjukkan ada perhatian dan keterampilan baru bagi anak SD dalam mengekstraksi minyak sereh wangi dan memformulasikannya sebagai obat cair yang siap disemprotkan ke dalam ruangan untuk mengusir nyamuk.
\end{abstract}

Kata Kunci: Malaria, Demam Berdarah, Anopheles, Aedes Aegepty, Sereh Wangi

Received: July 8, 2021

Revised: August 10, 2021

Accepted: September 1, 2021

\section{(i) (2)}




\section{Journal of Community Engagement in Health}

http://jceh.org

https://doi.org/10.30994/jceh.v4i2.252

ISSN: 2620-3758 (print); 2620-3766 (online)

Vol. 4 No 2. Sep 2021. Page. 348-354

\section{PENDAHULUAN}

Penyakit malaria dan demam berdarah adalah dua penyakit infeksi yang terjadi karena perantara nyamuk. Malaria disebabkan oleh infeksi parasit dengan vektor Anopheles sedangkan demam berdarah adalah infeksi virus Dengue fever dengan vektor Aedes aegepty. Kedua jenis penyakit inipun sangat rentan terjadi di wilayah tropis dan sub tropis seperti Indonesia, khsususnya di wilayah Pontianak yang dilewati garis khatulistiwa dan memiliki curah hujan tinggi sehingga berpotensi banyaknya genangan air yang terjadi setiap hujan turun. Prevalensi penderita malaria dan DBD di wilayah Pontianak cukup tinggi dan banyak terjadi pada anak sekolah umur 5-12 tahun karena frekuensi kontak dengan nyamuk di udara terbuka lebih lama terutama saat jam sekolah dari jam 07.00 sampai jam 14.00 WIB siang. Kalimantan Barat masih termasuk dalam 5 propinsi terbesar yang memiliki Incidence Rate (IR) per 100.000 orang penduduk tertinggi selain Propinsi Bali, Kalimantan Utara, Kalimantan Timur dan Kepulauan Riau dengan nilai IR masing-masing sebesar 204,20\%, 128,50\%, 131,10\% dan 92,60\% (DepKes, 2016).

Usaha menimbun genangan-genangan air, atau melakukan pengurasan pada genangan air yang lebih banyak, fogging di beberapa wilayah yang terindikasi ditemukan banyaknya penderita DBD maupun malaria sebagai salah satu intervensi pemerintah dalam menurunkan angka paparan penyakit malaria dan DBD ternyata juga tidak begitu efektif dalam memutus rantai penularan DBD dan malaria dalam suatu lingkungan, terutama di wilayah padat penduduk dan ramai dengan aktivitas. Secara individu, penggunaan anti nyamuk baik yang dibakar, maupun yang elektrik juga hanya menjauhkan nyamuk dan masa sementara saja sampai asapnya tercium, sehingga jika cairan untuk elektrik habis atau antinyamuk padatannya sudah habis terbakar, nyamuk pun akan kembali berdatangan. penanggulangan penyakit DBD. Upaya penanggulangan perkembangan nyamuk di lingkungan pemukiman akan sangat tergantung pada kekompakan dan harmonisasi dari seluruh pihak terkait, antara lain pemerintah setempat, masyarakat dan tokoh masyarakat serta ketersediaan sarana pelayanan kesehatan yang memadai dan layak bagi masyarakat.

Penggunaan insektisida dengan segala macam cara pemberian atau secara berlebihan, yang digunakan dalam waktu lama secara terus menerus akan berdampak buruk terhadap lingkungan. Penggunaan lotion antinyamuk yang dioleskan ke kulit pun akan berakibat mengiritasi kulit jika dipakai dalam jangka waktu lama. Hal ini melatarbelakangi diadakannya kegiatan oleh tim PKM Dosen Universitas Tanjungpura sebagai tim pelaksana dalam pelatihan pembuatan cairan spray anti nyamuk berbahan alami dari ekstrak minyak sereh wangi, yang dapat disemprotkan ke dalam ruangan dalam periode waktu tertentu sehingga nyamuk yang ada di dalamnya akan mati ataupun menjauh. Tanaman sereh wangi dapat dimanfaatkan sebagai anti nyamuk karena bau yang dihasilkan dari daun dan batangnya dapat mengusir nyamuk. Minyak sereh wangi adalah minyak atsiri yang diperoleh dengan cara menyuling daun dan batang sereh wangi. Kemampuan sereh wangi dalam mengusir nyamuk disebabkan oleh adanya kandungan senyawa geraniol, senyawa metil heptenon, senyawa terpen-terpen, dan asam-asam organic, terutama senyawa sitronela yang dapat digunakan sebagai obat nyamuk semprot (Frances, 2006). Jantan and Zaki (1998) melaporkan bahwa minyak atsiri dari sereh wangi dapat dimanfaatkan sebagai insektisida bersifat repellent yang dapat memberikan perlindungan dari gigitan nyamuk sampai sebesar 71,4\%.

Tujuan kegiatan PKM ini adalah untuk meningkatkan keterampilan siswa SD Muhamadiyah 2 Pontianak dalam membuat sediaan atau cairan spray antinyamuk berbahan ekstrak minyak sereh wangi untuk mengusir nyamuk yang dapat menyebabkan penyakit malaria dan penyakit DBD. Metode kegiatan ini didasarkan pada praktek mengekstraksi 


\section{Journal of Community Engagement in Health}

http://jceh.org

https://doi.org/10.30994/jceh.v4i2.252

ISSN: 2620-3758 (print); 2620-3766 (online)

Vol. 4 No 2. Sep 2021. Page. 348-354

minyak sereh wangi dan memformulasikannya dalam cairan antinyamuk spray yang dilanjutkan dengan pengujian aktivitas repellant dari sediaan yang telah diproduksi.

\section{METODE}

Pelaksanaan kegiatan PKM Pemanfaatan Sereh Wangi (Cymbopogon nardus) sebagai Cairan Spray Anti Nyamuk pada Murid Sekolah Dasar Muhammadiyah terdiri dari beberapa tahapan antara lain :

1. Konsolidasi Tim pelaksana dan Administrasi Perizinan

Konsolidasi tim dan pengurusan administrasi dilakukan secara daring dan memutuskan untuk pelaksanaan kegiatan ditempatkan di Laboratorium Ilmu Kelautan Fakultas MIPA Untan didasarkan pada penyiapan peralatan yang tidak memungkinkan untuk dibawa ke sekolah. Pelaksanaan kegiatan direncanakan berlangsung hari Sabtu 7 Agustus 2021.

2. Persiapan Peralatan dan Bahan

Alat dan bahan yang perlu dipersiapkan dalam pelaksanaan kegiatan ini antara lain adalah tanaman Sereh wangi, panci destilasi, kompor, gelas ukur, alkohol, air bersih, botol spray, botol pencampuran larutan.

3. Penyiapan poster kegiatan pelatihan yang berisi tentang materi pelatihan, serta form untuk evaluasi kegiatan yang dapat diedarkan saat berlangsungnya kegiatan.

4. Kegiatan dilaksanakan secara offline dan mengundang 15 peserta yang dibagi dalam 3 kelompok dalam melakukan praktek ekstraksi minyak sereh wangi dan memformulasikannya sebagai sediaan cari antinyamuk yang bersifat sebagai repellant.

5. Selanjutnya adalah monitoring dan evaluasi untuk melihat Pengujian aktivitas repellant dari produk yang dihasilkan adalah dengan membuat kotak pengujian sebanyak 2 buah yang dihubungkan dengan kanal/saluran, diisi dengan 20 ekor nyamuk dimana saat box yang satu disemprot dengan antinyamuk cair, maka nyamuk akan mengalami kematian atau lari ke kotak sebelahnya melalui pipa/kanal yang menghubungkannya. Kemampuan repellant atau mengusir nyamuk dari sediaan cair antinyamuk untuk spray ini dapat dilihat pada banyaknya nyamuk yang mengalami kematian atau berlari ke kotak sebelahnya yang tidak disemprot.

\section{HASIL}

Pelaksanaan kegiatan PKM Pemanfaatan Sereh Wangi (Cymbopogon nardus) sebagai Cairan Spray Anti Nyamuk pada Murid Sekolah Dasar Muhammadiyah diikuti oleh 15 peserta dan dibagi dalam 5 kelompok. Setiap kelompok diwakili 1 orang untuk melakukan kegiatan pengambilan sampel sereh wangi, ekstraksi minyak atsiri dari sereh wangi, formulasi cairan antinyamuk spray dan pengujian repellant dari produk yang telah dibuat.

Kegiatan dilakukan secara offline dengan tetap mematuhi protokol kesehatan yang ketat dalam usaha untuk memutus mata rantai penyebaran virus Covid 19. 


\section{Journal of Community Engagement in Health}

http://jceh.org

ISSN: 2620-3758 (print); 2620-3766 (online) https://doi.org/10.30994/jceh.v4i2.252

Vol. 4 No 2. Sep 2021. Page. 348-354
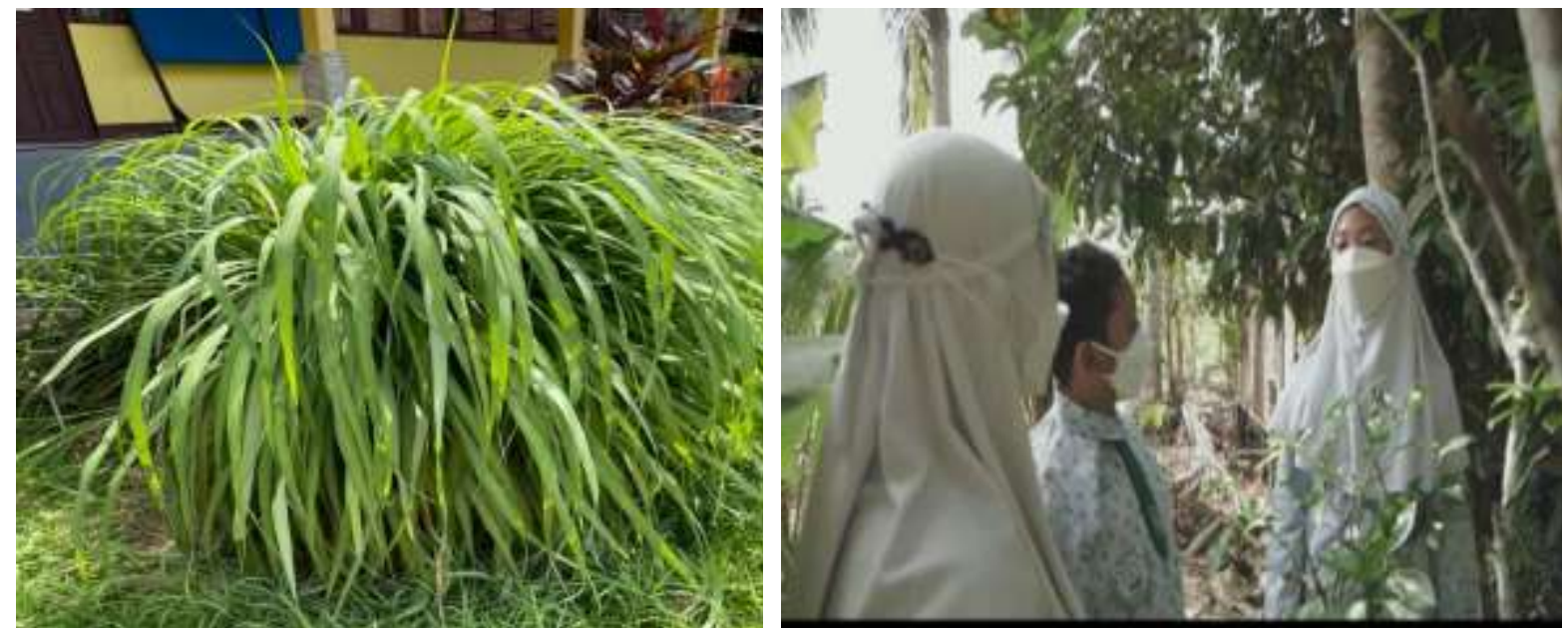

Gambar 1. Pengambilan sampel sereh wangi
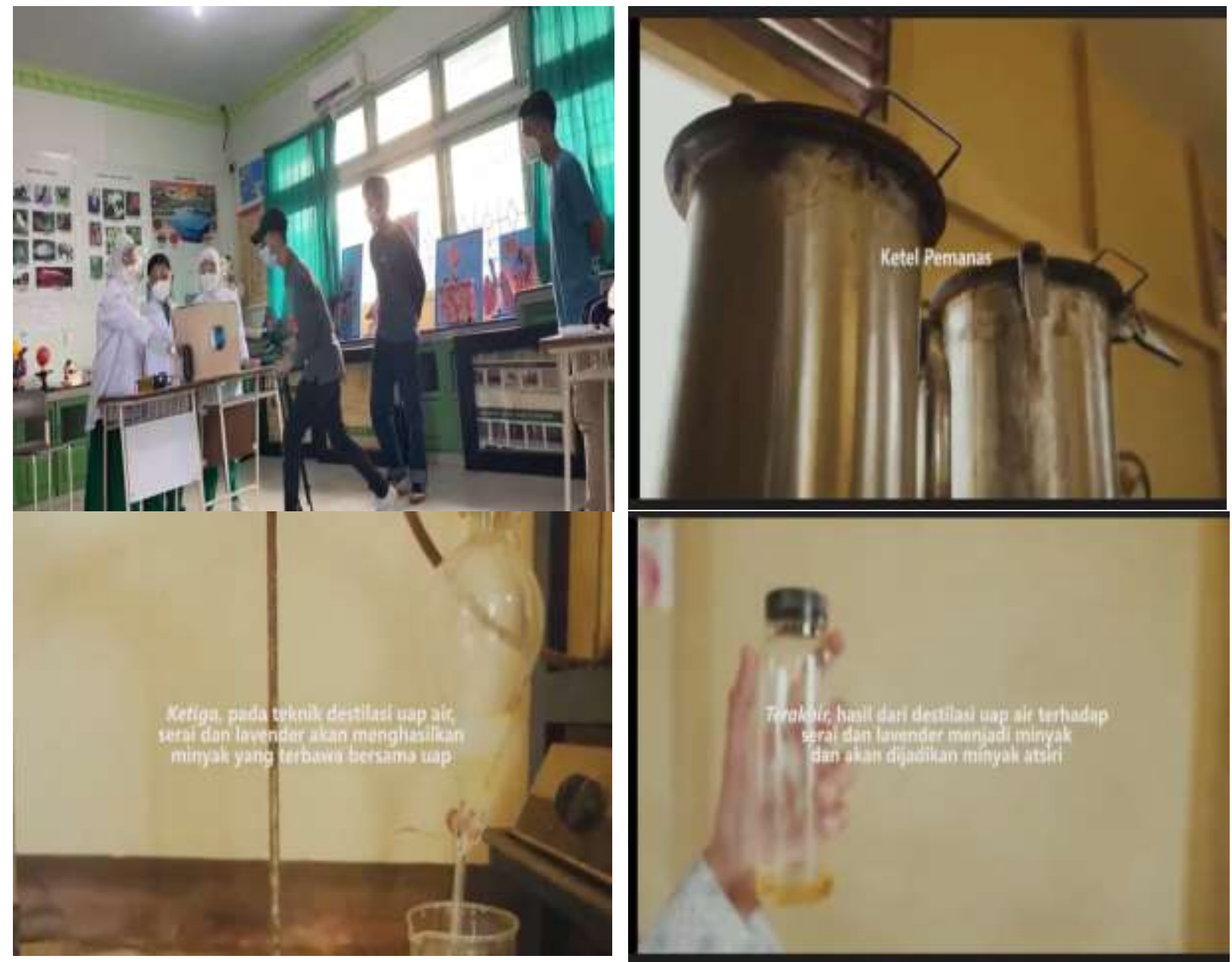

Gambar 2. Ekstraksi minyak sereh wangi 


\section{Journal of Community Engagement in Health}

http://jceh.org

ISSN: 2620-3758 (print); 2620-3766 (online)
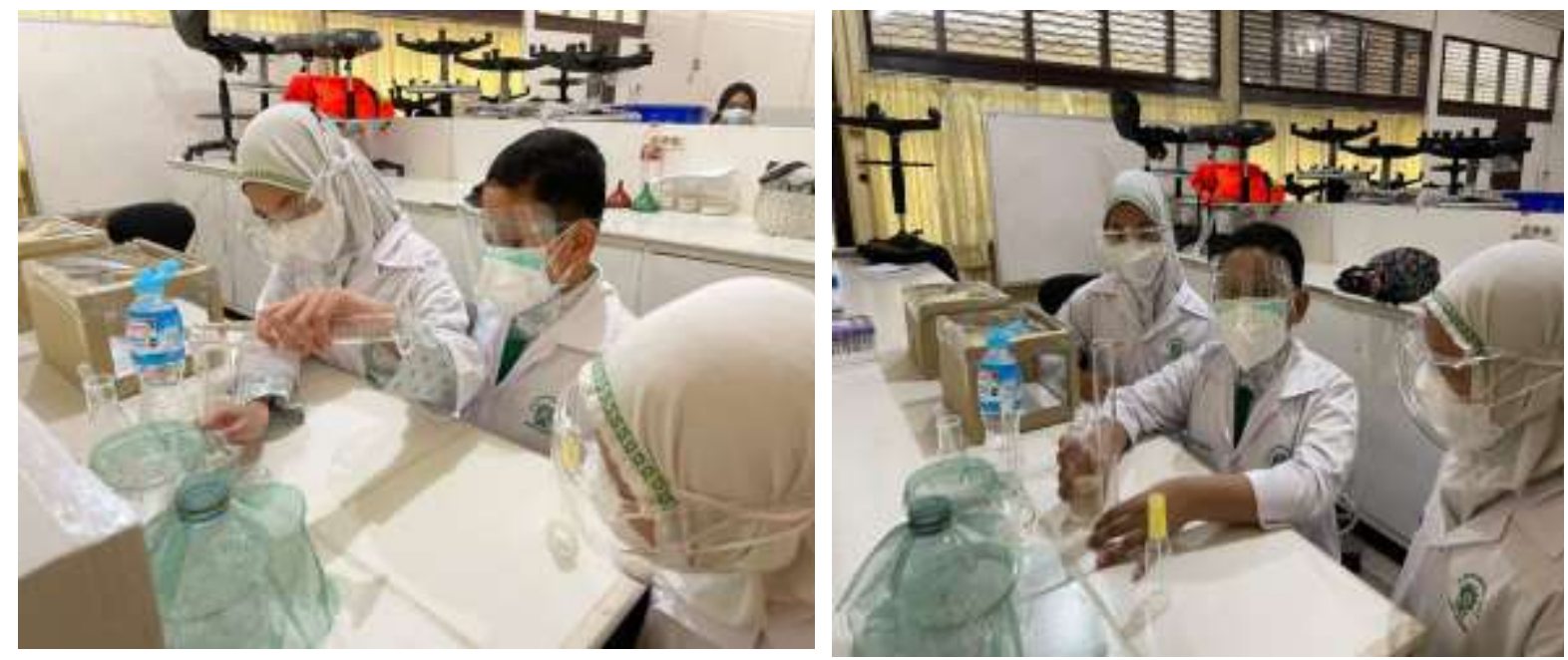

Gambar 3. Formulasi cairan antinyamuk Spray berbahan minyak sereh wangi
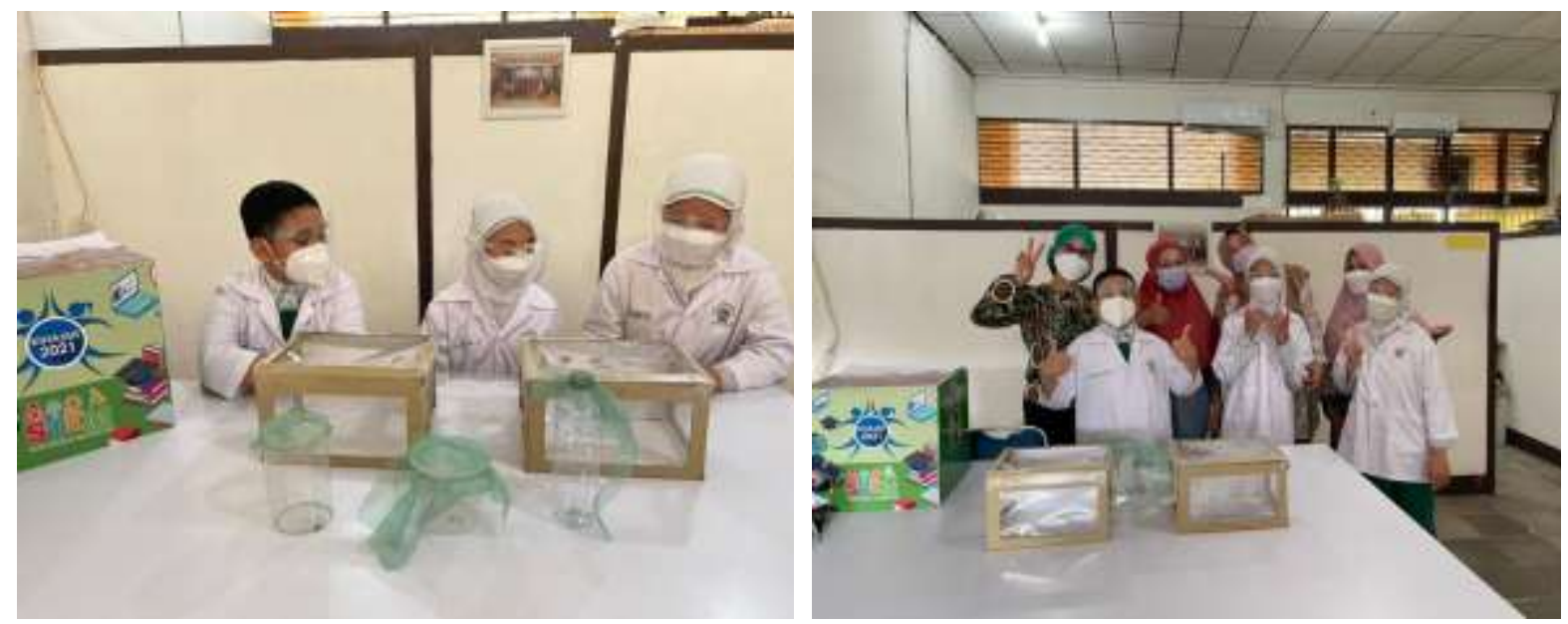

Gambar 4. Pengujian aktivitas repellant dari sediaan cair antinyamuk sereh wangi spray

\section{PEMBAHASAN}

Kondisi pemukiman penduduk yang padat dan ramai dalam suatu wilayah, kontur tanah yang berada jauh di permukaan laut sehingga banyak rawa yang saat musim hujan dan banjir rob akan mengalami genangan, sangat berpotensi tinggiya perkembangbiakan nyamuk yang secara signifikan akan meningkatkan jumlah penderita DBD dan malaria (Abdullah, AZ, dkk, 2010). Suhu udara yang rendan dalam lingkungan pemukiman warga juga berpotensi meningkatkan penularan DBD oleh nyamuk Aedes aegepty (Syauqiannur, dkk, 2019). Pengendalian penyakit malaria dan DBD sampai saat ini belum bisa dicegah dengan vaksin, sehingga hanya dapat dilakukan beberapa usaha preventif untuk menekan laju perkembangan nyamuk Aedes aegepty sebagai vector pembawa virus, demikian juga menekan laju pertumbuhan nyamuk Anopheles sebagai vector pembawa parasite plasmodium untuk penyakit malaria.

Wilayah Kalimantan Barat dengan incidence rate sebesar 111,10\% masih termasuk dalam 5 besar Propinsi di Indonesia yang memiliki paparan penyakit DBD tertinggi. Demikian juga engan penyakit malaria, Kalimantan Barat masih tergolong sebagai wilayah yang rentan dengan wabah Malaria. Berbagai usaha telah dilakukan untuk menekan laju pertumbuhan kedua nyamuk penyebab infeksi malaria dan DBD ini adalah dengan fogging, pemakaian 


\section{Journal of Community Engagement in Health}

http://jceh.org

https://doi.org/10.30994/jceh.v4i2.252

ISSN: 2620-3758 (print); 2620-3766 (online)

Vol. 4 No 2. Sep 2021. Page. 348-354

kelambu, abatisasi, penggunaan repellant pada kulit dan usaha-u saha lainnya tapi masih belum cukup efektif menurunkan resiko tinggi terutama di musim hujan.

Kegiatan PKM terkait usaha pencegahan nyamuk Aedes aegepty dan Anopheles dilakukan dengan pelatihan pembuatan cairan antinyamuk spray berbahan baku minyak sereh wangi pada siswa SD Muhammadiyah Pontianak, mengingat anak usia 5-12 tahun, yaitu anak usia Sekolah Dasar sangat rentan terinfeksi virus DBD, dan penularannya terjadi di jam-jam sekolah atau bermain, jika tidak menggunakan pelindung kulit dari gigitan nyamuk. Kegiatan ini ditujukan untuk memberikan bekal pengetahuan dan keterampilan kepada siswa Sekolah Dasar Muhammadiyah untuk dapat memanfaatkan tumbuhan di lingkungan sekitarnya dalam membuat cairan antinyamuk yang dapat mengusir nyamuk dari ruangan, sehingga badan terbebas dari gigitan nyamuk dalam masa waktu tertentu. Metode kegiatan ini adalah secara praktis, melakukan pembuatan cairan antinyamuk spray yang apat diaplikasikan dalam kehidupan sehari-hari sebagai usaha untuk mencegah terjadinya infeksi Kegiatan ini diikuti oleh 15 orang siswa yang dibagi dalam 3 kelompok dan masing-masing kelompok diwakili oleh 1 orang untuk melakukan ekstraksi minyak sereh wangi dan dilanjutkan dengan formulasi cairan antinyamuk spray uamg siap digunakan. Dalam kegiatan ini juga dilakukan evaluasi produk cairan antinyamuk spray yang dihasilkan dengan melakukan pengujian repellant dari produk cairan antinyamuk tersebut menggunakan kotak uji berukuran $20 \times 30 \times 20 \mathrm{~cm}^{3}$ sebanyak 2 buah yang terhubung dengan kanal berdiameter $3 \mathrm{~cm}$ di mana satu kotak yang berisi nyamuk 20 ekor diberikan semprotan anti nyamuk sereh wangi, hasilnya adalah seluruh nyamuk yang ada di kotak yang telah disemprot akan berlari ke kotak sebelahnya. Ini menunjukkan bahwa wangi antinyamuk dari sereh wangi tersebut dapat mengusir nyamuk. Dari hasil evaluasi ini menunjukkan bahwa cairan antinyamu spray yang diproduksi oleh siswa SD Muhammadiyah sebagai peserta dalam kegiatan pelatihan ini dianggap berhasil, karena $100 \%$ nyamuk uji berpindah ke kotak yang tidak diberian sereh wangi. Cairan sereh wangi ini dapat diaplikasikan langsung di rumah maupun di sekolah, dengan cara menyemprotkan dalam ruang terbuka ataupun tertutup, sehingga selama wangi masih ada tercium dalam ruangan, nyamuk tidak akan mendekat.

\section{KESIMPULAN}

Dari kegiatan PKM Pemanfaatan Sereh Wangi (Cymbopogon nardus) sebagai Cairan Spray Anti Nyamuk pada Murid Sekolah Dasar Muhammadiyah 2 Pontianak, dapat disimpulkan sebagai berikut :

1. Peserta kegiatan pelatihan telah mampu mengekstraksi minyak sereh wangi secara destilasi uap panas dan memformulasikan sediaan cair antinyamuk spray sebagai repellant (pengusir nyamuk)

2. Sediaan cair antinyamuk yang dihasilkan dari kegiatan terbukti dapat mematikan $100 \%$ nyamuk uji yang ada di dalam kotak pengujian aktivitas repellant.

\section{REFERENSI}

Abdullah AZ, Nawi R, Sibe A. 2010, Faktor Risiko Kejadian Demam Berdarah Dengue di Kecamatan Tempe Kabupaten Wajo 2009. Media Kesehatan Masyarakat Indonesia.; 6(4):198-203.

Dinas Kesehatan Provinsi Kalimantan Barat. Profil Kesehatan Provinsi Kalimantan Barat Tahun 2015. Pontianak: Dinas Kesehatan Provinsi Kalimantan Barat; 2016.

Direktorat Jenderal Pengendalian Penyakit dan Penyehatan Lingkungan. Pedoman Penatalakasanaan Kasus Malaria Di Indonesia. Jakarta: Departemen Kesehatan RI;2008 


\section{Journal of Community Engagement in Health}

http://jceh.org

https://doi.org/10.30994/jceh.v4i2.252

ISSN: 2620-3758 (print); 2620-3766 (online)

Vol. 4 No 2. Sep 2021. Page. 348-354

Depkes R.I. (2000). Pencegahan dan.Penanggulangan DBD dan DB. Jakarta:.Dirjen PPM dan PLP.

Frances, P. 2006. Efficacy and Safety of Repellents Containing Deet. Pp. 319 in Insect Repellents, Principles, Methode, and Uses. (M. Debboun, P. Frances, and D. Strickman, eds.). Boca Raton: CRC Press.

Halstead, S.B. (2000). Successes and Failure.in Dengue Control Global Experiences. Dengue Bulletin, Vol. 24. 60-70.

Jantan, I. and Z.M. Zaki. 2001. Evaluation of Smoke from Mosquito Coils Containing Malaysian Plants Against \$HGHVDHJ \SWL. )LWRWHUDSLD. 70:237-243

Syarif Syauqiannur, Agus Fitriangga, Muhammad Pramulya, 2019, Sebaran kasus dan faktor risiko kejadian DBD berbasis SIG Kabupaten Kubu Raya tahun 2016-2018.

WHO. (2004). Panduan Lengkap Pencegahan..dan Pengendalian Dengue dan Demam.Berdarah Dengue. Jakarta: EGC. 